\title{
Bioactivity of Algerian palm dates Phoenix dactylifera L.
}

\author{
Fatma Mihoub, Freha Gourchala, Safia Lakhdar-Toumi
}

\author{
Ibn Khaldoun University, Tiaret, Algeria
}

\section{Keywords:}

Antibacterial

Activity

Phoenix dactylifera $L$.

Dates

Algeria

\section{Article history:}

Received 29.10.2018

Received in revised

form 24.02.2019

Accepted 31.05.2019

\section{Corresponding \\ author:}

Fatma Mihoub

E-mail:

mihoub2@yahoo.fr

DOI: $10.24263 / 2304-$

974X-2019-8-2-5

\section{Abstract}

Introduction. The current study was conducted in order to evaluate in vitro the phytochemical profile and antibacterial activity of Algerian palm dates Phoenix dactylifera $L$.

Materials and methods. Qualitative and quantitative (total polyphenols, flavonoids and antioxidant activity)phytochemical analysis were performed on aqueous and methanolic extracts of seven varieties of dates as the evaluation of antibacterial activity against Staphylococcus aureus ATCC 25923 and Escherichia coli ATCC 25922 strains.

Results and discussion. Phytochemical screening of aqueous and methanolic extracts showed the presence of several families of chemical compounds such as catechin tannins, saponins and terpenoids in the seven varieties of dates. The screening of these extracts reveals slight qualitative differences with a greater presence of saponins in the aqueous extract while terpenoids are present in large quantity in the methanolic extract. A quantitative characterization of extracts showed significantly high levels $(P<0.05)$ in the methanolic extract from: $85.8 \pm 0.8$ to $275 \pm 0.07 \mathrm{GAE} / 100 \mathrm{~g}, 36.9 \pm 0.3$ to $70.1 \pm 0.9 \mathrm{QE} / 100 \mathrm{~g}$ and $18.5 \pm 0.9$ to $58.5 \pm 0.5 \%$ vs. $66.1 \pm 0.2$ to $189 \pm 0.09 \mathrm{GAE} / 100 \mathrm{~g}, 29.1 \pm 0.5$ to $50.8 \pm 0.6 \mathrm{QE} / 100 \mathrm{~g}$ and $14.7 \pm 0.4$ to $41 \pm 0.1 \%$ in aqueous extracts for total polyphenols, flavonoids and reducing power respectively. The susceptibility of bacterial species to various extracts of Phoenix dactylifera L. fruits by agar well diffusion assay showed a maximum inhibition zone diameter (IZD) of $43.0 \pm 1.0$ and $26.3 \pm 1.5$ $\mathrm{mm}$ for the methanolic extract of the variety Tamesrit against $S$. aureus and $E$. coli strains respectively. The minimum inhibitory concentrations (MIC) ranged from $0.08 \mathrm{~g} / \mathrm{mL}$ for the methanolic extract of the variety H'mira against $E$. coli to less than $0.04 \mathrm{~g} / \mathrm{mL}$ for the methanolic extracts of the varieties Tamesrit, Akerbouch and Bent Kbala against S. aureus.

Conclusion. Given the interesting contents of polyphenols, flavonoids and antioxidant activity in addition to the inhibitory power of date extracts, we can conclude that this product could be an excellent source of antioxidants and bioconservatives in food preparation. 


\section{Introduction}

The use of antibiotics is currently contested due in part to their high costs and potential toxicological risks and on the other hand, their frequent consumption could lead to resistance of strains and be responsible for therapeutic failures [1,2]. Secondary metabolites are natural plant compounds, available at low cost. Due to their natural antioxidant and antibacterial effects, they can constitute pharmacological alternatives for the prevention and the treatment of several pathologies [3, 4]. For thousands of years, dates, fruits of Phoenix dactylifera L., are known to have many medicinal properties and in countries ranging from the Near East to the Middle East are used in traditional medicine as protectors and curatives [5-7]. Moreover, this fruit having many favorable biological properties as antioxidant, antimicrobial.... [8,9]. In Algeria, the date occupies a very important place with an average annual production estimated at 1029596 tons; this allowed him to occupy the world's third largest producer of date [10]. But its valuation and exploitation as sources of natural bioactive substances endowed with antibacterial activity which presents an interest in the field of biopharmaceuticals are very limited. The objective of this study is to evaluate in vitro bioactivity of seven varieties of Algerian dates on phytochemical profile and antibacterial activity against two bacterial strains (Staphylococcus aureus, Escherichia coli) frequent in human pathology and often responsible for food poisoning.

\section{Materials and methods}

\section{Plant material}

Seven (07) date palm cultivars at the "Tmar" stage (maturity stage) locally known as: H'mira, Adhem Fgig,BouzrourAkerbouch, Bentkbala, Ghars and Tamesrit from the region of Ghardaia (southern Algeria) were used for the experimentation. $10 \mathrm{~kg}$ of each variety harvested (season 2017) in the same locality were provided by farmers. After cleaning, samples were placed in hermetic bags and stored at $4{ }^{\circ} \mathrm{C}$ until analysis.

\section{Extract preparation}

The pulps of each variety previously cleaned and ground, constitute the raw material for extracts. For aqueous extract, $10 \mathrm{~g}$ of each variety are mixed with $100 \mathrm{~mL}$ of distilled water and continuous stirred for $2 \mathrm{~h}$ at room temperature then filtered. The methanolic extract is prepared by mixing $10 \mathrm{~g}$ of pulps to $50 \mathrm{~mL}$ of methanol/water $(80: 20, \mathrm{~V} / \mathrm{V})$, placed under slow stirring for $24 \mathrm{~h}$ at room temperature then reduced under pressure in a rota-vapor to remove methanol.

\section{Phytochemical analysis}

Phytochemical analysis on aqueous and methanol/water extracts of dates was determined. Some phytochemical groups have been characterized, according to the methods described by Ciulei [11], tannins by the $\mathrm{FeCl}_{3}$ test; alkaloids per Dragendorff reagent, the saponins per froth test, terpenoïds by Salkowski reaction (to $0.5 \mathrm{~g}$ of the extract were added to $2 \mathrm{ml}$ of chloroform and $3 \mathrm{ml}$ of concentrated sulfuric acid $\mathrm{H}_{2} \mathrm{SO}_{4}$ where a reddish-brown color indicates the presence of terpenoids) [12] and anthocyanins using $\mathrm{HCl}$ and $\mathrm{NH}_{4} \mathrm{OH}$ test 
[13]. The total phenolics contents were determined using Folin-Ciocalteau reagent according to Singleton and Rossi method [14] using gallic acid as standard. The results are expressed in $\mathrm{mg}$ of Gallic Acid Equivalent (GAE)/100g of fresh weight. The flavonoids amount is determined according to Lamaison and Carnat [15] method using quercitin as standard; the results are displayed in $\mathrm{mg}$ of Quercitin Equivalent $/ 100 \mathrm{~g}$ of fresh weight. The antioxidant activity is performed according to the FRAP method [16], the results obtained are expressed in $\mathrm{mg}$ of vitamin $\mathrm{C}$ per $100 \mathrm{~g}$ of the fresh fruit.

\section{Antibacterial susceptibility assay}

Bacterial strains. Two ATCC reference bacterial strains were used for the antibacterial susceptibility assay of different date extracts: Staphylococcus aureus ATCC 25923 and Escherichia coli ATCC 25922 stored at $-20{ }^{\circ} \mathrm{C}$ in glycerol.

Agar well diffusion assay and determination of MIC. The potential antibacterial activity of the aqueous and methanolic extracts of the pulp of the different cultivars was evaluated in vitro by the standard agar well diffusion assay [17]. From a culture of the bacterial suspension of 18 hours at $37^{\circ} \mathrm{C}$, an inoculum adjusted to 0.5 Mac Farland density (a dilution of 1/10th and 1/100th of the bacterial suspension respectively of $S$. aureus and $E$. coli was performed in sterile distilled water before inoculation [18]) was seeded uniformly by tight streaks with a sterile cotton swab on the surface of the Petri dish $(90 \mathrm{~mm})$ containing $20 \mathrm{~mL}$ of Muller Hinton agar. Four wells/dish of $6 \mathrm{~mm}$ diameter each were perforated in the agar with the tip of a sterile Pasteur pipette and filled with $100 \mu \mathrm{L}$ of aqueous or methanolic palm dates extracts $(0.20 \mathrm{~g} / \mathrm{mL})$. All plates were incubated for $24 \mathrm{~h}$ at $37^{\circ} \mathrm{C}$. The antibacterial activity is evaluated by measuring the diameter of the inhibition zone (IZD) formed around the well. The percentage of growth inhibition is calculated by the formula: $\mathrm{I} \%=$ IZD/PDD*100 (IZD: Inhibition Zone Diameter, DD: Petri Dish Diameter=90mm) [19]. For assessment of minimum inhibitory concentration (MIC), the incorporation technique in agar is used [20] with some modifications. A concentration range of the aqueous and methanolic crude extracts was prepared respectively in water and methanol/water to have final concentrations of $0.04,0.08,0.12,0.16$ and $0.20 \mathrm{~g} / \mathrm{mL} .2 \mathrm{~mL}$ of each extract were incorporated in $18 \mathrm{~mL}$ of Muller Hinton agar maintained liquid and all is well stirred. After the agar plates completely solidified, $100 \mu \mathrm{L}$ of the bacterial suspension already adjusted under the same conditions described above are inoculated by swabbing at the surface of the dish and all is incubated for $24 \mathrm{~h}$ at $37^{\circ} \mathrm{C}$. The $\mathrm{CMI}$ is defined as the lowest concentration at which there is no visible growth [21]. The solvents used for the preparation of extracts (distilled water and methanol/water) are used as negative controls. While some antibiotics are used as positive controls to check their effects on the growth of each germ and are compared to the critical values of the diameters of

the zones of inhibition data by CA-SFM/EUCAST [22].These are: Tetracycline

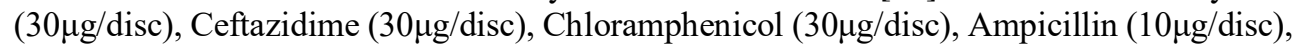
Fosfomycin $(200 \mu \mathrm{g} / \mathrm{disc})$, Cefazolin $(30 \mu \mathrm{g} / \mathrm{disc})$ and Colistin sulfate $(10 \mu \mathrm{g} / \mathrm{disc})$.

\section{Statistical analysis}

Each assay was carried out in triplicate. All experiments are expressed as mean \pm standard deviation (SD). The data were treated using the STATISTICA software (Version 8) by the ANOVA test followed by the Duncan test for multiple comparisons. 


\section{Results and discussion}

Phytochemical characterization of date extracts

Phytochemical screening of aqueous and methanolic date extracts

Table 1

\begin{tabular}{|l|l|l|l|l|l|l|}
\hline \multirow{2}{*}{ Varieties } & Saponins & Catechic tannins & Terpenoids & Anthocyans & Alkaloids \\
\cline { 2 - 7 } & \multicolumn{5}{|c|}{ Aqueous extract } \\
\hline Ghars & +++ & ++ & + & - & - \\
\hline Tamesrit & +++ & ++ & ++ & - & - \\
\hline AdemFgig & +++ & + & ++ & - & - \\
\hline Akerbouch & +++ & +++ & ++ & - & - \\
\hline BentKbala & +++ & +++ & ++ & - & - \\
\hline Bouzror & ++ & +++ & ++ & - & - \\
\hline H'mira & ++ & +++ & ++ & - & - \\
\hline \multicolumn{7}{|c|}{ Methanolic extract } \\
\hline Ghars & ++ & ++ & ++ & - & - \\
\hline Tamesrit & ++ & ++ & +++ & - & - \\
\hline AdemFgig & ++ & + & +++ & - & - \\
\hline Akerbouch & ++ & +++ & +++ & - & - \\
\hline BentKbala & ++ & +++ & +++ & - & - \\
\hline Bouzror & + & +++ & +++ & - & - \\
\hline H'mira & + & +++ & +++ & - & - \\
\hline
\end{tabular}

+++ Very intense, ++ intense, + weak, - absent

Qualitative phytochemical analysis (Table 1) detected the presence of saponins, tannins and terpenoids in (methanolic/aqueous) date extracts.

The results depended on the reactions, going from clearly to weakly positive. These observations are similar to those reported by others authors indicating that Phoenix dactylifera fruit is a potential source of secondary metabolites [23-24]. A comparison of date extracts composition found that methanolic extracts presented greats levels of terpenoids than aqueous ones witch possessed more saponins, while both extracts had the same tannins contents. These results indicated the influence of the extraction solvent on the total content of secondary metabolites. Similar findings were obtained by others studies [25-27]. In contrast, anthocyans and alkaloids were absents in all date extracts.

Quantitative analysis of the composition on secondary metabolites showed a significant difference between the seven date cultivars extracts contents (Table 2). Tamesrit variety gave the highest levels of flavonoids and total polyphenols, followed by Akerbouch and BentKbala varieties thus reflecting interesting antioxidants activities with 58.5, 50.2 and 40.8\% respectively. The aqueous extract revealed a low content of antioxidant compounds compared to the metanolic extract. Moreover, the antioxidant activity is inversely proportional to the richness in antioxidant compounds on the aqueous extract however, it seems to be more proportional to the flavonoids levels on the methanolic extracts; theses phytochemicals are a group of polyphenolic compounds, which have multiples pharmacological properties, they 
presents strong antioxidant power [7] and could participate also in antibacterial activity [28$31]$.

Polyphenols, flavonoids contents and antioxidant activity of aqueous and

Table 2 methanolic date extracts

\begin{tabular}{|c|c|c|c|}
\hline $\begin{array}{l}\text { Compounds } \\
\text { Varieties }\end{array}$ & $\begin{array}{l}\text { Polyphenols } \\
\text { (mg GAE/100g) }\end{array}$ & $\begin{array}{l}\text { Flavonoids } \\
\text { (mg QE/100g) }\end{array}$ & $\begin{array}{l}\text { Antioxidant } \\
\text { activity (\%) }\end{array}$ \\
\hline \multicolumn{4}{|c|}{ Aqueous extract } \\
\hline Ghars & $76.5 \pm 0.7^{\mathrm{d}}$ & $30.9 \pm 0.9^{\mathrm{e}}$ & $36.9 \pm 0.1^{\mathrm{b}}$ \\
\hline Tamesrit & $189 \pm 0.09^{\mathrm{a}}$ & $46.7 \pm 0.3^{b}$ & $14.7 \pm 0.4^{\mathrm{e}}$ \\
\hline Adhem Fgig & $66.1 \pm 0.2^{\mathrm{e}}$ & $29.1 \pm 0.5^{\mathrm{f}}$ & $41 \pm 0.1^{\mathrm{a}}$ \\
\hline Akerbouch & $123 \pm 1.1^{\mathbf{b}}$ & $50.8 \pm 0.6^{\mathrm{a}}$ & $16.4 \pm 0.8^{\mathrm{d}}$ \\
\hline Bent Kbala & $121 \pm 0.9^{\mathbf{b}}$ & $36 \pm 0.7^{\mathrm{d}}$ & $17.8 \pm 0.7^{\mathrm{d}}$ \\
\hline Bouzrour & $88.5 \pm 0.8^{c}$ & $41 \pm 0.2^{\mathrm{c}}$ & $28.9 \pm 0.9^{\mathbf{c}}$ \\
\hline H'mira & $89.2 \pm 0.6^{\mathbf{c}}$ & $31.2 \pm 0.1^{\mathrm{e}}$ & $29.7 \pm 1.2^{\mathrm{c}}$ \\
\hline \multicolumn{4}{|c|}{$\begin{array}{l}\text { Methanolic extract } \\
\end{array}$} \\
\hline Ghars & $103 \pm 1.1^{\mathrm{e}}$ & $41 \pm 0.3^{\mathrm{e}}$ & $21.3 \pm 1.3^{\mathrm{e}}$ \\
\hline Tamesrit & $275 \pm 0.07^{\mathrm{a}}$ & $67.2 \pm 1.2^{\mathrm{a}}$ & $58.5 \pm 0.5^{\mathrm{a}}$ \\
\hline Adhem Fgig & $85.8 \pm 0.8^{\mathrm{f}}$ & $36.9 \pm 0.3^{\mathrm{f}}$ & $18.5 \pm 0.9^{\mathrm{f}}$ \\
\hline Akerbouch & $173 \pm 0.6^{\text {ab }}$ & $70.1 \pm 0.9^{\mathrm{a}}$ & $50.2 \pm 0.4^{\mathrm{b}}$ \\
\hline Bent Kbala & $172 \pm 0.2^{\mathrm{b}}$ & $50 \pm 0.9^{\mathrm{c}}$ & $40.8 \pm 2.5^{\mathbf{c}}$ \\
\hline Bouzrour & $117.5 \pm 0.5^{d}$ & $55 \pm 1.0^{\mathrm{b}}$ & $36.2 \pm 0.9^{d}$ \\
\hline H'mira & $123 \pm 1.1^{\mathrm{c}}$ & $44.3 \pm 0.9^{\mathrm{d}}$ & $23.7 \pm 0.3^{\mathrm{e}}$ \\
\hline
\end{tabular}

The means followed by the letters $\mathrm{a}, \mathrm{b}, \mathrm{c}, \mathrm{d}$, e and $\mathrm{f}$ in the same column are significantly different $(\mathrm{p}<0.05)$.

\subsection{Antibacterial activity of date extracts}

The antibacterial activity of the aqueous and methanolic extracts of the seven date varieties against two pathogenic bacterial (Escherichia coli ATCC 25922 and Staphylococcus aureus ATCC 25923) revealed that the aqueous extracts have not expressed inhibition zones around the wells, whereas methanolic extracts showed a strong antibacterial activity against the two bacterial strains. Our results are in a good concordance with some studies like [32-33]. The difference between the antibacterial activities could be explained by the nature and the concentration of the metabolites content in each type of extract. Indeed, the ability to extracting and solubilizing phytomolecules is very different and depends strongly on the solvent type [34-35]. According to Cowan [36], it could be deduced that the antibacterial substances contained in dates are more soluble in methanol.

Moreover, the active extracts were significantly more effective $(P<0.05)$ on $S$. aureus (IZD: 15 to $43 \mathrm{~mm}$ ) than on E. coli (IZD: 11 to $27 \mathrm{~mm}$ ) (Table 3). The resistance of Gramnegative bacteria may be due to the presence of lipopolysaccharides in their cell wall, thus preventing the possible active components of date extracts to crossing and lysing their cytoplasmic membranes [25, 37]. 
Antibacterial activity of methanolic dates extracts compared to antibiotics

\begin{tabular}{|l|l|l|l|l|l|}
\hline \multirow{2}{*}{ Varieties } & \multicolumn{2}{|c|}{ IZD $^{*}(\mathbf{m m})$} & \multirow{2}{*}{ Antibiotics } & \multicolumn{2}{c|}{ IZD $^{*}(\mathbf{m m})$} \\
\cline { 2 - 3 } \cline { 5 - 6 } & $\boldsymbol{E}$. coli & S. aureus & & E. coli & S. aureus \\
\hline Ghars & $18.7 \pm 0.6^{\mathbf{d}}$ & $26.3 \pm 1.5^{\mathbf{c d}}$ & Cefazolin & $24.6 \pm 1.1^{\mathbf{b}}$ & $32.6 \pm 0.7^{\mathbf{a}}$ \\
\hline Tamesrit & $26.3 \pm 1.5^{\mathbf{a b}}$ & $43.0 \pm 1.0^{\mathbf{a}}$ & Colistin sulfate & $13.0 \pm 1.7^{\mathbf{e}}$ & $16.0 \pm 2.1^{\mathbf{d}}$ \\
\hline AdemFgig & $24.7 \pm 1.2^{\mathbf{b}}$ & $24.3 \pm 2.1^{\mathbf{d}}$ & Tetracycline & $10.0 \pm 1.4^{\mathbf{f}}$ & $26.0 \pm 1.2^{\mathbf{c}}$ \\
\hline Akerbouch & $27.0 \pm 1.0^{\mathbf{a}}$ & $35.3 \pm 3.1^{\mathbf{b}}$ & Ampicillin & $21.0 \pm 0.6^{\mathbf{c}}$ & $25.0 \pm 1.0^{\mathbf{c}}$ \\
\hline BentKbala & $25.3 \pm 0.6^{\mathbf{a b}}$ & $29.3 \pm 0.15^{\mathbf{c}}$ & Fosfomycin & $35.0 \pm 1.5^{\mathbf{a}}$ & $29.0 \pm 2.5^{\mathbf{b}}$ \\
\hline Bouzror & $22.0 \pm 1.0^{\mathbf{c}}$ & $27.0 \pm 1.0^{\mathbf{c d}}$ & Ceftazidime & $6.0 \pm 0.1^{\mathbf{g}}$ & $6.0 \pm 0.0^{\mathbf{f}}$ \\
\hline H'mira & $11.0 \pm 1.0^{\mathbf{e}}$ & $15.0 \pm 0.1^{\mathbf{e}}$ & Chloramphenicol & $20.3 \pm 0.4^{\mathbf{d}}$ & $7.6 \pm 0.0^{\mathbf{e}}$ \\
\hline
\end{tabular}

* Mean values \pm SD, $n=3(p<0.05)$, IZD: Inhibition Zone Diameter. The Means followed by the letters $\mathrm{a}, \mathrm{b}, \mathrm{c}, \mathrm{d}, \mathrm{e}, \mathrm{f}$ and $\mathrm{g}$ in the same column are significantly different $(\mathrm{p}<0.05)$

The methanolic extract of Tamesrit variety which was significantly $(\mathrm{p}<0.05)$ the most effective, showed the maximum IZD against $S$. aureus $(43 \mathrm{~mm}$ : nearly $50 \%$ of the population were inhibited) and E. coli (26.3 mm: nearly $30 \%$ of the population were inhibited) (Table 4).

Table 4

Minimum inhibitory concentration (MIC) and percentages of growth inhibition of methanolic dates extracts

\begin{tabular}{|c|c|c|c|c|c|c|c|}
\hline \multirow{3}{*}{ Varieties } & \multicolumn{7}{|c|}{ E. coli } \\
\hline & \multicolumn{5}{|c|}{ Concentration of extract $(\mathrm{g} / \mathrm{mL})$} & \multirow{2}{*}{$\begin{array}{c}\text { MIC } \\
(\mathrm{g} / \mathrm{mL})\end{array}$} & \multirow{2}{*}{$\mathrm{I} \%$} \\
\hline & 0.20 & 0.16 & 0.12 & 0.08 & 0.04 & & \\
\hline Ghars & - & - & - & - & + & 0.08 & 20.8 \\
\hline Tamesrit & - & - & - & - & + & 0.08 & 29.2 \\
\hline AdemFgig & - & - & - & - & + & 0.08 & 27.4 \\
\hline Akerbouch & - & - & - & - & + & 0.08 & 30.0 \\
\hline BentKbala & - & - & - & - & + & 0.08 & 28.1 \\
\hline Bouzror & - & - & - & - & + & 0.08 & 24.4 \\
\hline H'mira & - & - & - & + & + & 0.12 & 12.2 \\
\hline \multirow{3}{*}{ Varieties } & \multicolumn{7}{|c|}{ S. aureus } \\
\hline & \multicolumn{5}{|c|}{ Concentration of extract $(\mathrm{g} / \mathrm{mL})$} & \multirow{2}{*}{$\begin{array}{c}\mathrm{MIC} \\
(\mathrm{g} / \mathrm{mL})\end{array}$} & \multirow{2}{*}{$\mathrm{I} \%$} \\
\hline & 0.20 & 0.16 & 0.12 & 0.08 & 0.04 & & \\
\hline Ghars & - & - & - & - & + & 0.08 & 29.2 \\
\hline Tamesrit & - & - & - & - & - & $<0.04$ & 47.8 \\
\hline AdemFgig & - & - & - & - & + & 0.08 & 27.0 \\
\hline Akerbouch & - & - & - & - & - & $<0.04$ & 39.2 \\
\hline BentKbala & - & - & - & - & - & $<0.04$ & 32.6 \\
\hline Bouzror & - & - & - & - & + & 0.08 & 30.0 \\
\hline H'mira & - & - & - & - & + & 0.08 & 16.7 \\
\hline
\end{tabular}

+: presence of growth, -: no growth, I\%: The percentage of growth inhibition 

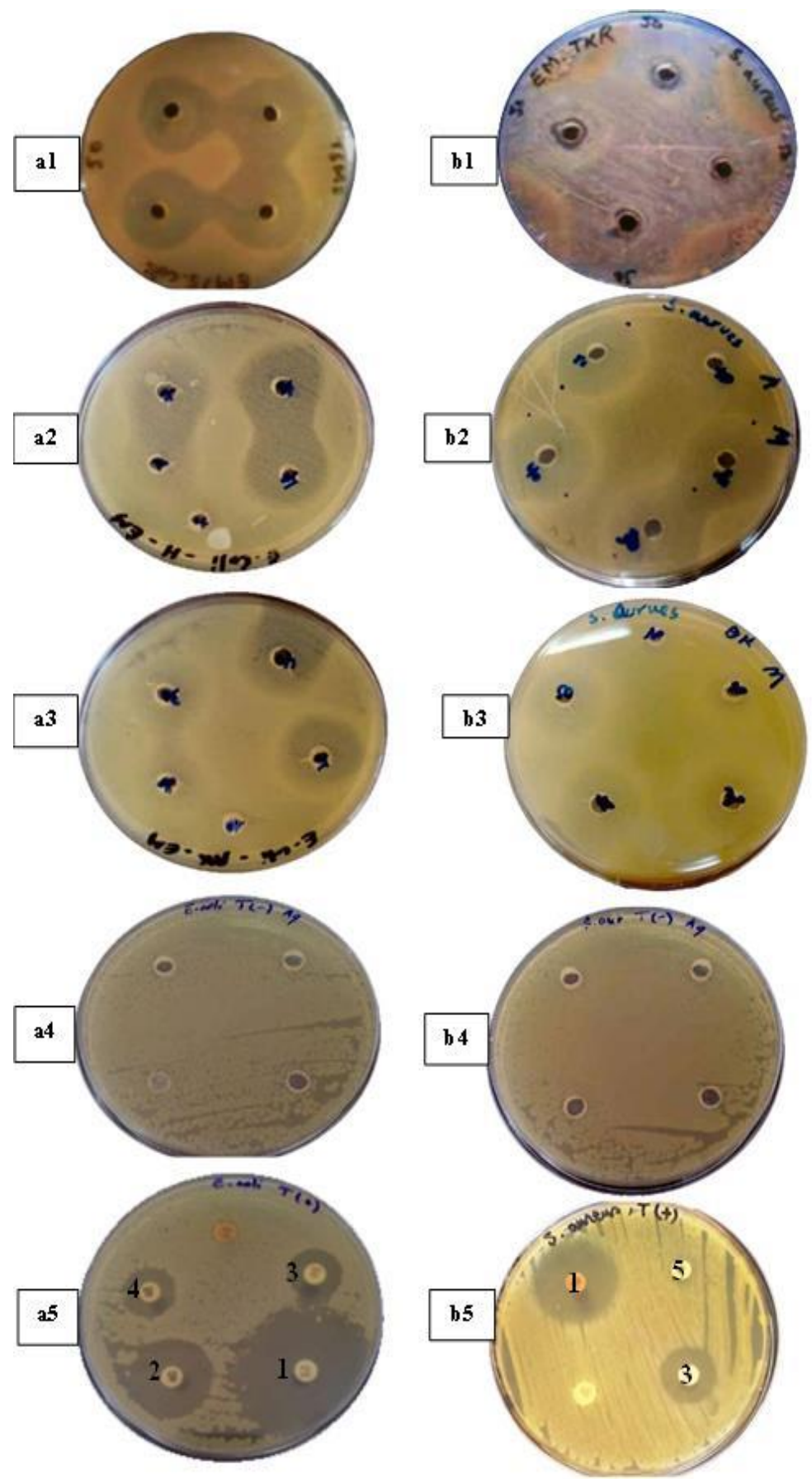

Figure 1. Antibacterial activities of methanolic extracts of some date's varieties compared with negative (a4, b4) and positive (a5, b5) controls against $E$. coli (a) and $S$. aureus (b) strains 
Antibiotics for positive control: 1: Fosfomycin, 2: Cefazolin, 3: Colistin sulfate,

Designation in Figure 1

4: Tetracyclin, 5: Chloramphenicol

a1, a2 and a3: effect of Tamesrit, Akerbouch and Bent Kbala respectively against $E$. coli

b1, b2 and b3: effect of Tamesrit, Akerbouch and Bent Kbala respectively against $S$. aureus

Minimum inhibitory concentration (MIC) values below $0.04 \mathrm{~g} / \mathrm{mL}$ are noted for Tamesrit, Akerbouch and Bent Kbala extracts againstS. aureus (Table 4). Whereas for both strains, a MIC of $0.08 \mathrm{~g} / \mathrm{mL}$ is recorded for the methanolic extracts of majority of dates cultivars excepting H'mira extract which showed a MIC of $0.12 \mathrm{~g} / \mathrm{mL}(\mathrm{I} \%=12.2 \%)$ to inhibit the growth of $E$. coli.

Extracts of Akerbouch and Bent Kbala varieties gave an interesting IZD for Gram positive bacteria of 35.3 to 29.3 respectively $\mathrm{mm}$ and for Gram negative bacteria of 27 to $25.3 \mathrm{~mm}$ respectively (Table 3 , Figure 1 ). A study conducted on the bacterial activity of three Algerian varieties Ghars, Deglet Nour and Mech Degla on some bacterial species gave IZDs of 7.5 to $9.5 \mathrm{~mm}$ against $E$. coli which are clearly lowers to the diameters we obtained with all methanolic extracts on the same germ [38].However a study of the antibacterial activity of methanolic extracts of Saudi dates gave IZDs of $16 \pm 0.20 \mathrm{~mm}$ on S. aureus and $11 \pm 0.00$ $\mathrm{mm}$ on $E$. coli[35];these values correspond to the minimum IZDs found for our varieties. In another study, the antibacterial activity of methanolic Nigerian dates extracts gave IZDs of 12 to $18 \mathrm{~mm}$ against $E$. coli [39]; values comparable to those obtained with H'mira and Ghars cultivars extracts in the present study which exhibit the lowest antibacterial activity.

On the other hand, for the control antibiotics used, Fosfomycin and Cefazolin gave a maximum inhibition diameter of $32.6 \mathrm{~mm}$ and $35 \mathrm{~mm}$ against $S$. aureus and E. coli respectively. The interest of the results we obtained is that all the antibiotics showed an antibacterial activity comparable to that of dates extracts or even less than some (Table 3). Effectively, the methanolic extract of Tamesrit variety (IZD=43 mm) was more active $(P<0.05)$ than all antibiotics against $S$. aureus (IZD maximum of $32.6 \mathrm{~mm}$ for cefazolin). The results of this study showed that $S$. aureus were highly resistant to Chloramphenicol and ceftazidime while $E$. coli resisted to ceftazidime and tetracycline versus the active methanolic extracts of the different date cultivars. The presence of flavonoids, saponins, terpenoids and tannins, may be involved in the bioactivity of plant extracts, these chemical groups have been demonstrated in other studies conducted on the evaluation of antibacterial activity [29]. The studied dates extracts (Table 1) contain heterogeneity of chemical compounds that could explain the antibacterial activity observed.

\section{Conclusion}

The sensitivity of the studied bacteria ( $S$. aureus and E. coli) was more apparent for the extracts of Tamesrit variety followed by those of Akerbouch and Bent Kbala, this result is very important because it provides an answer element for the choice of some dates varieties for a possible therapeutic use. The date could be used as a bioconservative in the food industry which gives added value to this fruit playing both a role of preservative and stabilizer during food storage by their antibacterial effects but also able to improve their organoleptic and nutritional qualities by its contribution in interesting elements such as the polyphenolic compounds and the antioxidant power, so it would be a very interesting functional food ingredient. The difference between the antibacterial activity of the two date extracts (aqueous 
and methanolic) is difficult to explain because both extracts contained all sought metabolites, but not in the same proportions. So, identification and quantification of active components is necessary and could shed more light on the difference in the biological activities of dates extracts.

\section{References}

1. Gold S.G., Moellering R.C.(1996), Antimicrobial drug resistance, The New England Journal of Medicine, 335, pp. 1445-1453.

2. Fymat A.L.(2017), Antibiotics and Antibiotic Resistance, Biomedical Journal of Scientific and Technical Research, 1(1), pp. 65-80.

3. Ali-Shtayeh M.S., Yaghmour R.M.R., Faidi Y.R., Salem K., Al-Nuri M.A. (1998), Antimicrobial activity of 20 plants used in folkloric medicine in the Palestinian area, Journal of Ethnopharmacology, 60, pp. 265-271.

4. Mostafa A.A., Al-Askar A.A., Almaary K.S., Dawoud T.M., Sholkamy E.N., Bakri M.M. (2018), Antimicrobial activity of some plant extracts against bacterial strains causing food poisoning diseases. Saudi Journal of Biological Sciences, 25, pp. 253-258.

5. Al-Farsi M.A., Lee C.Y. (2008),Nutritional and functional properties of dates: A review, Critical Reviews in Food Science and Nutrition, 48, pp. 877-887.

6. Harrak H., Boujnah M. (2012), Valorisation technologique des dattes au Maroc, INRA (eds), pp. 1-160.

7. Vayalil P.K.(2012), Date fruits (Phoenix dactylifera Linn): An emerging medicinal food, Critical Reviews in Food Science and Nutrition, 52, pp. 249-271.

8. Al-Shahib W., Marshall R.J.(2003), The fruit of the date palm: Its possible use as the best food for the future?, International Journal of Food Science and Nutrition, 54, pp. 247-259.

9. Mansouri A., Embarek G., Kokkalou E., Kefalas P. (2005), Phenolic profile and antioxidant activity of the Algerian ripe date palm fruit (Phoenix dactylifera), Food Chemistry, 89, pp. 411-420.

10. FAOSTAT (2018), Food and Agriculture Organization of the United Nations, Available at: http://www.fao.org/faostat/fr/\#data/QC/visualize.

11. Ciulei I. (1982), Practical Manuals on the Industrial Utilization of Chemical and Aromatic Plants. Methodology for Analysis of Vegetable Drugs. 1st ed., Ministry of Chemical Industry, Bucharest.

12. Pushker A.K., Kaushik S., Lakhanpaul S., Sharma K.K., Ramani R.(2011) Preliminary phytochemical investigation on the bark of some of the important host plants of Kerria lacca - the Indian lac insect, Botany Research International, 4, pp. 48-51.

13. Bruneton J. (2009), Pharmacognosie: Phytochimie, plantes médicinales, 4ème éditions médicales internationales, Tec \& Doc, Paris.

14. Singleton V.L., Rossi J.A.(1965), Colorimetry of Total Phenolics with Phosphomolybdic-Phosphotungstic Acid Reagents, American Journal of Enology and Viticulture, 16, pp. 144-158.

15. Lamaison J.L., Carnat A. (1991), Contents of principal flavonoïdes in flowers and leaves of Crataegus monogyna Jacq. and Crataegus laevigata (Poiret) DC., in function of the vegetation. Medecinal Plants Phytotherapy, 25, pp. 12-16.

16. Oyaizu M. (1986), Studies on Products of Browning Reactions: Antioxidative Activities of Product of Browning Reaction Prepared from Glucosamine, Japan Journal of Nutrition, 44, pp. 307-315. 
17. Valgas C, De Souza S.M., Smânia E.F.A., Smânia A.J.R. (2007), Screening Methods To Determine Antibacterial Activity of Natural Products, Brazilian Journal of Microbiology, 38, pp. 369-380.

18. Andrews J.M. (2008), BSAC standardized disc susceptibility testing method (version 7), Journal Antimicrobial Chemotherapy, 62, pp. 256-278.

19. Himratul-Aznita W.H., Mohd-Al-Faisal N., Fathilah A.R. (2011), Determination of the percentage inhibition of diameter growth (PIDG) of Piper betle crude aqueous extract against oral Candida species, Journal of Medicinal Plants Research, 5, pp. 878-884.

20. Waites K.B., Duffy L.B., Bébéar C.M., Matlow A., Talkington D.F., Kenny G.E., et al.(2012), Standardized methods and quality control limits for agar and broth microdilution susceptibility testing of Mycoplasma pneumoniae, Mycoplasma hominis, and Ureaplasma urealyticum, Journal of Clinical Microbiology, 50, pp. 3542-3547.

21. Andrews J.M. (2001), Determination of minimum inhibitory concentrations, Journal Antimicrobial Chemotherapy, 48, suppl., pp. 5-16.

22. CA-SFM / EUCAST. (2018), Comité de l'antibiogramme de la Société Française de Microbiologie, Available at: www.sfm-microbiologie.org.

23. Allaith A.A.A. (2007), Antioxidant activity of Bahraini date palm (Phoenix dactylifera L.) fruit of various cultivars, International Journal of Food Science and Technology, 43, pp. 1033-1040.

24. Anjum F.M., Bukhat S.I., El-Ghorab A.H., Khan M.I., Nadeem M., Hussain S., Arshad M.S. (2012),Phytochemical characteristics of Date Palm (Phoenix dactylifera) fruit extracts, Pak. J. Food Sci 22, pp. 117-127.

25. Saleh F.A., Otaibi M.M. (2013), Antibacterial Activity of Date Palm (PhoenixDectylifera L.) Fruit at Different Ripening Stages, Journal of Food Process and Technology, 4, pp. 1-6.

26. Daas Amiour S., Alloui-Lombarkia O., Bouhdjila F., Ayachi A., Hambaba L. (2014), Étude de l'implication des composés phénoliques des extraits de trois variétés de datte dans son activité antibactérienne, Phytotherapie, 12, pp. 135-142.

27. Qadoos H.A., Dhafari H.S., Al Marzooqi D.A., Yaqoubi A.I., Kumarappan A., Nazir A., Elsori D.H. (2017), Phenolic Content and Antimicrobial activities of Date Palm (Phoenix dactylifera L.) Fruits and Leaves, Food Biology, 6, pp. 11-15.

28. Mehmood N., Zubair M., Rizwan K., Rasool N.(2012),Antioxidant, Antimicrobial and Phytochemical Analysis of Cichorium intybus Seeds Extract and Various Organic Fractions, Iranian Journal of Pharmaceutical Research, 11, pp. 1145-1151.

29. El-Sohaimy S.A., Abdelwahab A.E., Brennan C.S., Aboul-enein A.M. (2015), Phenolic content, antioxidant and antimicrobial activities of Egyptian date palm (Phoenix dactylifera L.) fruits, Australian Journal of Basic and Applied Sciences. 9, pp. 141-148.

30. Zehra S., Saeed A., Fatima S. (2015), Antioxidant and antibacterial studies of Phoenix dactylifera and its varieties, International Journal of Applied Microbiological and Biotechnological Research, 3, pp. 81-88.

31. Samad M.A., Hashim S.H., Simarani K., Yaacob J.S. (2016),Antibacterial properties and effects of fruit chilling and extract storage on antioxidant activity, total phenolic and anthocyanin content of four date palm (Phoenix dactylifera) cultivars, Molecules, 21, pp. 1-14.

32. Kaushik P., Goyal P., Chauhan A., Chauhan G. (2010), In vitro evaluation of antibacterial potential of dry fruitextracts of Elettaria cardamomum Maton (Chhoti Elaichi), Iranian Journal of Pharmaceutical Research. 9, pp. 287-292. 
33. Perveen K., Bokhari N.A., Soliman D.A.W. (2012), Antibacterial activity of Phoenix dactylifera $L$. leaf and pit extracts against selected Gram negative and Gram positive pathogenic bacteria, Journal of Medicinal Plants Research.6, pp. 296-300.

34. Biglari F., AlKarkhi A.F.M., Easa A.M. (2008), Antioxidant activity and phenolic content of various date palm (Phoenix dactylifera) fruits from Iran, Food Chemistry. 107, pp. 1636-1641.

35. Bhat R.S., Al-daihan S. (2012), Antibacterial properties of different cultivars of Phoenix dactylifera L. and their corresponding protein content, Annals of Biological Research.3, pp. 4751-4757.

36. Cowan M.M. (1999), Plant products as antimicrobial agents, Clinical Microbiology Reviews, 12, pp. 564-582.

37. Ahmad I., Beg A.Z. (2001), Antimicrobial and phytochemical studies on 45 Indian medicinal plants against multi-drug resistant human pathogens, Journal of Ethnopharmacology, 74, pp. 113-123.

38. Ayachi A., Alloui N., Bennoune O., Yakhlef G., Daas Amiour S., Bouzid W., Djemai Zoughlache S., Boudjellal K., Abdessamed H. (2009), Antibacterial Activity of Some Fruits; Berries and Medicinal Herb Extracts Against Poultry Strains of Salmonella. American-Eurasian Journal of Agriculture and Environmental Sciences, 6, pp. 12-15.

39. Sani N.M., Abdulkadir F., Mujahid N.S. (2017), Antimicrobial activity of Phoenix dactylifera (date palm) on some selected members of Enterobacteriaceae, Bayero Journal of Pure Applied Sciences, 10, pp. 36-39. 